\title{
Privatization, Ownership Structure, and Bank Risk Taking: the Case of Commercial Banks in China
}

\author{
Shun-Ho Chu1,a, Haitian Chen ${ }^{1, b}$ and Shuo Yan1,c \\ $1_{\text {Macau University of Science and Technology, Macau, China }}$ \\ ashchu@must.edu.mo, bseasky5207@hotmail.com, cyanshuo1991@hotmail.com
}

Keywords: total risk, bank-specific risk, systematic risk, bank privatization

\begin{abstract}
After opening financial market for foreign institutions, commercial banks in China have been encountered foreign and domestic competition seriously. The results of this study are that bank assets have a significantly negative relationship with total risk and bank-specific risk, whereas nondirector shareholdings and non-performing loans has a significantly positive relation with total risk and bank-specific risk. Secondly, growth rate of GDP has positive relation with systematic risk. Other factors have no significant relation with bank risks.
\end{abstract}

\section{Introduction}

Bank privatization is a complex process of financial liberalization [1], which increases banks efficiency, and also allows banks to expand risk-taking activities [2]. In 2001, China was allowed to join in WTO with the conditional terms of opening domestic financial markets commencing form 2006. During the period of 2001-2006, country-owned banks were partially privatized and listed in Shanghai and Shenzhen Stock Exchange and Hong Kong Stock Exchange. According to the Management Regulation of Foreign Banks announced in 2006, foreign financial institutions including foreign branches, join-ventured banks, and subsidiaries are allowed to enter into domestic markets, which have benefit for Chinese financial institutions to improve financial innovations and upgrade banking management skills, especially risks management. Conversely, Chinese financial institutions have been encountered serious competition. Competition is one of external factors affecting banks to take risks. Bank management will search for more risk as charter value of bank diminishes in the competitive conditions [3]. Then, an increase in bank competition will lead to a decrease in charter value of bank.

\section{Review of Literature}

Charter value of banks is the future profits resulted from regulatory restrictions on entry, branching, and competition [4]. Saunders and Wilson support that relationship between bank risk and charter value is positive [5]. Haq and Heaney find that charter value has a significantly negative relationship with credit risk but a positive relationship with total risk [6]. Financial liberalization and increasing competition will diminish charter value [3].

Assets size of bank may affect undertaking of bank risks [6]. Several studies have the opposite evidence that there is a significantly negative relationship $[7,8]$ due to the skills of risk management, opportunities of risk diversification, and competence of risk diversification owned by large-scaled banks [9].

Trading frequency reflects the information related to assets, liabilities, and off-balance sheet activities of banks on the speed of stock prices [10]. Trading frequency is measured by the ratio of daily trading volume to number of outstanding common stocks [8]. Anderson and Fraser find that banks having high trading frequency have ability to undertake the higher level of bank risks [8].

Performance of banks in the developing countries after privatization and have empirical findings that privatized banks controlled by local conglomerates tend to search for credit risk and interest risk [1]. Due to the policy of financial liberalization, private investors are allowed to purchase stakes of commercial banks and also become as an important parts of bank capitals. However, 
private investors tend to be risky reference, and prop bank management to undertake more risky activities in order to make maximum benefits for stockholders.

Institutional investors provide the secondary function to supervise banks and expect the risk taken by banks to be complied with maximum benefits of stockholders [11]. Commercial banks accept foreign banks as banks directors and/or supervisors in order to share experience of bank management from foreign banks. The bank with directors and supervisors acted by foreign banks less tend to search for undertaking of bank risks.

\section{Data and Methodology}

The data were collected from the websites of commercial banks in China listed in Shanghai Stock Exchange for the analysis based on the criteria of a balance panel data approach. Semiannual data from January 2008 to June 2012 were used and yielded a total of 108 observations. The study selects 12 banks from 14 listed commercial banks except of China Everbright Bank and Agricultural bank of China due to their listed year of 2010.

This study takes reference to the empirical regression model used by Anderson and Fraser [8] to examine the determinants of bank risk taking. The regression model of this study is as follows:

$$
\text { Risk }_{i t}=\beta_{0}+\beta_{1} L N S I Z E_{i t}+\beta_{2} C V_{i t}+\beta_{3} F H_{i t}+\beta_{4} N D H_{i t}+\beta_{5} T F_{i t}+\beta_{6} N P L_{i t}+\beta_{7} G D P_{i t}+\beta_{8} H K_{i t}+\varepsilon_{i t}
$$

where Risk $k_{i t}$ expresses total risk, bank-specific risk, and systematic risk for bank i in each semiannual $\mathrm{t} ; \mathrm{LNSIZE}_{i t}$ is the natural logarithm of total assets; $C V_{i t}$ is measured by Keeley's $\mathrm{Q}$ as charter value; $F H_{i t}$ is ratio of number shares held by foreign investors to total shares outstanding; $N D H_{i t}$ is ratio of number of shares held by non-director investors to total shares outstanding; $T F_{i t}$ is defined ratio of daily trading number of shares to total shares outstanding as trading frequency; $N P L_{i t}$ is ratio of non-performing loans to total loans; $G D P_{i t}$ is growth rate of GDP; $H K_{i t}$ is a dummy variable. If bank i listed in Hong Kong Stock Exchange, dummy variable is 1; otherwise, it is $0 . \quad \beta_{0}$ is constant item. $\varepsilon_{i t}$ is error term.

The dependent variables of this study were total risk, bank-specific risk, and systematic risk. This study use proxy of standard deviation of returns of bank stocks as index of total risk. Based on single-factor CAPM, this study uses proxy of standard deviation of errors as bank-specific risk. Then, systematic risk is total risk subtracted by bank-specific risk [12]. The independent variables included total assets, charter value, foreign shareholdings, non-directors holdings, trading frequency, non-performing loans. A control variable is growth rate of GDP and a dummy variable is the list in Hong Kong Stock Exchange. If listed in Hong Kong Stock Exchange, the dummy variable of bank is 1 , otherwise dummy variable is 0 .

\section{Empirical results}

Table 1 presents descriptive statistics for the dependent and independent variables. Correlation among independent variables is shown on Table 2. 
Table 1. Descriptive statistics for selected variables

\begin{tabular}{lcccc}
\hline Variables & Maximum & Minimum & Mean & St. Deviation \\
\hline TR & 0.062901 & 0.006224 & 0.023469 & 0.012027 \\
BSR & 0.059944 & 0.005069 & 0.021775 & 0.012236 \\
SR & 0.010292 & -0.000850 & 0.001694 & 0.002743 \\
LNSIZE & 16.65300 & 11.408810 & 14.57677 & 1.213534 \\
CV & 9.101500 & 0.784508 & 1.114150 & 0.777191 \\
FH & 0.471459 & 0.000000 & 0.172428 & 0.156940 \\
NDH & 1.000000 & 0.998988 & 0.999861 & 0.000292 \\
TF & 0.036408 & 0.000081 & 0.004436 & 0.004954 \\
NPL & 0.026500 & 0.003500 & 0.010832 & 0.005014 \\
GDP & 0.433256 & -0.177529 & 0.080133 & 0.234962 \\
HK & 1.000000 & 0.000000 & 0.416667 & 0.495305 \\
\hline
\end{tabular}

Table 2. Correlation matrix of independent variables

\begin{tabular}{lcccccccc}
\hline Variables & LNSIZE & CV & FH & NDH & TF & NPL & GDP & HK \\
\hline LNSIZE & 1.0000 & & & & & & & \\
CV & -0.2514 & 1.0000 & & & & & & \\
FH & 0.5029 & 0.0023 & 1.0000 & & & & & \\
NDH & 0.7109 & -0.2901 & 0.2010 & 1.0000 & & & & \\
TF & 0.4843 & -0.0107 & -0.6303 & -0.2091 & 1.0000 & & & \\
NPL & 0.1420 & 0.0845 & 0.4180 & 0.0283 & -0.2741 & 1.0000 & & \\
GDP & -0.0231 & -0.0567 & -0.0018 & 0.0092 & -0.0347 & 0.0458 & 1.0000 & \\
HK & 0.7491 & -0.0671 & 0.6281 & 0.4012 & -0.5252 & 0.3817 & -8.9157 & 1.0000 \\
\hline
\end{tabular}

Selecting random effect model or fixed effect model by Hausman test is to enter into empirical study. According to the results of Hausman test shown on Table 3, this study selects random effect model.

Table 3. Results of Hausman test

\begin{tabular}{lccc}
\hline Model & $\chi^{2}$ & d.f. & Prob. \\
\hline Model 1 & 0.000000 & 6 & 1.0000 \\
Model 2 & 0.000000 & 6 & 1.0000 \\
Model 3 & 4.143107 & 6 & 0.6573 \\
\hline
\end{tabular}

The table 4 presents the empirical results of the OSL regression analysis for three models. The degree of fitness of regression model 1, model 2, and model 3 can be explained by the adjusted $\mathrm{R}^{2}$ of 0.582578, 0.529279, and 0.309910, respectively. Model 1 and model 2 have the better explanatory power for total risk and bank-specific risk, whereas model 3 has low level of explanatory power for systematic risk. Durbin-Watson values of three models are 1.966310, 1.965774, and 1.951711, respectively, which is no existence of autocorrelation.

Through statistically empirical analysis, bank assets have a significantly negative relationship with total risk and bank-specific risk. Secondly, non-director shareholdings have a significantly positive relationship with total risk and bank-specific risk. Thirdly, the growth rate of GDP has a significantly positive relationship with systematic risk. Fourthly, others factors including charter value, foreign shareholding, trading frequency are not significantly related with bank risks. Finally, The thing of listed or not in Hong Kong Stock Exchange has not related to bank risks. 
Table 4. Empirical results of the OSL regression

\begin{tabular}{|c|c|c|c|}
\hline Variables & Total risk & Bank-specific risk & Systematic risk \\
\hline \multirow[t]{2}{*}{ LNSIZE } & -0.010735 & -0.009335 & -0.000218 \\
\hline & {$[-4.009414] * * *$} & {$[-3.311728] * * *$} & {$[-0.534078]$} \\
\hline \multirow[t]{2}{*}{$\mathrm{CV}$} & 0.000092 & 0.000074 & 0.000029 \\
\hline & [0.095627] & [0.070425] & [0.092936] \\
\hline \multirow[t]{2}{*}{$\mathrm{FH}$} & -0.013947 & -0.016934 & 0.001558 \\
\hline & [-1.193459] & [-1.361209] & {$[0.727400]$} \\
\hline \multirow[t]{2}{*}{$\mathrm{NDH}$} & 25.72726 & 22.30235 & 0.449419 \\
\hline & {$[2.893509] * * *$} & {$[2.416156] * *$} & [0.383495] \\
\hline \multirow[t]{2}{*}{$\mathrm{TF}$} & 0.233475 & 0.168775 & 0.062541 \\
\hline & [1.196845] & {$[-4.009414]$} & [1.022705] \\
\hline \multirow[t]{2}{*}{ NPL } & 1.462505 & 1.550002 & 0.007787 \\
\hline & {$[6.498011] * * *$} & {$[6.448891] * * *$} & {$[0.149471]$} \\
\hline \multirow[t]{2}{*}{ GDP } & 0.003422 & -0.003009 & 0.006512 \\
\hline & [1.183713] & {$[-0.955368]$} & {$[6.751921] * * *$} \\
\hline \multirow[t]{2}{*}{ HK } & 0.009487 & 0.008746 & -0.000820 \\
\hline & [1.442290] & [1.283163] & {$[-0.998951]$} \\
\hline R-squared & 0.613787 & 0.564473 & 0.361505 \\
\hline Adjusted R-squared & 0.582578 & 0.529279 & 0.309910 \\
\hline F statistic & 19.66693 & 16.03885 & 7.006524 \\
\hline Durbin-Watson stat & 1.966310 & 1.965774 & 1.951711 \\
\hline
\end{tabular}

\section{Conclusions}

The empirical results of this study are that bank assets have a significantly negative relationship with total risk and bank-specific risk, whereas non-director shareholdings and non-performing loans has a significantly positive relation with total risk and bank-specific risk. Secondly, growth rate of GDP has positive relation with systematic risk.

According to the empirical results and advanced analysis, some suggestions are presented by the study for commercial banks in China. Firstly, bank assets have negative effect on total risk and bank-specific risk, which imply large-sized commercial banks have cushioned for bank risks. Secondly, non-directors shareholding have voting right to affect the main decisions of banks. It is essential for bank management should fully disclose information as a key medium to communication with mass common stockholders. Thirdly, commercial banks suffer losses of nonperforming loans, which may lead to deterioration of the health of commercial banks. Therefore, commercial banks should have well-established risk systems to manage and monitor bank risks.

\section{References}

[1] N. Boubakri, J. Cosset, K. Fischer and O. Guedhami: Privatization and Bank Performance in Developing Countries. Journal of Banking \& Finance, Vol.29 (2005), pp. 2015-2041.

[2] G. Clarke, R. Cull and M.M. Shirley: Bank Privatization in Developing Countries: A Summary of Lessons and Findings. Journal of Banking \& Finance, Vol.29 (2005), pp. 10951930.

[3] M.C. Keeley: Deposit Insurance, Risk, Make Power in Banking. American Economic Review, Vol.80 (1990), pp. 1183-1200.

[4] T.M. Galloway, W.B. Lee and D.M. Roden: Bank's Changing Incentives and Opportunities for Risk Taking, Journal of Banking \& Finance, Vol. 21 (1997), pp. 509-527.

[5] A. Saunder and B. Wilson: An Analysis of bank Charter value and Its risk Constraining Incentives. Journal of Financial Service Research, Vol.19 (2001), pp. 185-195.

[6] M. Haq and R. Heaney: Factors Determining European Bank Risk, Journal of Banking \& Finance, Vol.22 (2012), pp. 696-718.

[7] A. Saunders, E. Strock and N.G. Travos: Ownership Structure, Deregulation, and Bank Risk Taking, Journal of Finance, (1990), pp. 643-654.

[8] R.C. Anderson and D.R. Fraser: Corporate Control, Bank Risk Taking, and the Health of the Banking Industry. Journal of Banking \& Finance, Vol.24 (2000), pp.1383-1398. 
[9] N. Zribi and Y. Boujelbêne: The Factors Influencing Bank Credit Risk: The Case of Tunisia, Journal of Accounting and taxation, Vol.3 (2011), pp. 70-78.

[10] R. Demsetz and P. Strahan: Diversification, Size, and Risk at Bank Holding Companies, Journal of Money, Credit, and Banking, Vol.29 (1997), pp. 300-313.

[11] J.D. Knopf and J.L. Teall: Risk-Taking Behavior in the US Thrift Industry: Ownership Structure and Regulatory Changes, Journal of Banking \& Finance, Vol.20 (1996), pp. 13291350.

[12] J.G. Gallo, V.P. Apilado and J.W. Kolari: Commercial Bank Mutual Fund Activities: Implications for Bank Risk and Profitability. Journal of Banking \& Finance, Vol.20 (1996), pp. 1775-1791. 